\title{
Morainal-bank sediment budgets and their influence on the stability of tidewater termini of valley glaciers entering Glacier Bay, Alaska, U.S.A.
}

\author{
Lewis E. Hunter, \\ U.S. Army Cold Regions Research and Engineering Laboratory, 72 Lyme Road, Hanover, NH 03755, U.S.A. \\ Ross D. Powell, \\ Department of Geology, Northern Illinois University, DeKalb, IL 60115, U.S.A. \\ Daniel E. LAWSON \\ U.S. Army Cold Regions Research and Engineering Laboratory, 72 Lyme Road, Hanover, NH 03755, U.S.A.
}

\begin{abstract}
Investigations of grounding-line sedimentation in front of tidewater termini of temperate valley glaciers demonstrate that sediment yields and dynamics provide a second-order control on glacier stability by influencing water depth at the grounding line. Sediment is delivered to the grounding line by two routes: (1) debris transported in, on and beneath the glacier, and (2) sediment transported in glacial outwash streams. Glacial streams in Glacier Bay, Alaska, U.S.A., deliver $10^{6}$ to $10^{7} \mathrm{~m}^{3}$ year ${ }^{1}$ of sediment to the grounding lines. The glacial debris flux transports $10^{5}$ to $10^{6} \mathrm{~m}^{3}$ year $^{-1}$ of debris to the ice cliffs, where approximately $10 \%$ is released at the grounding line, the remainder being transported downfjord by iceberg-rafting. An additional $10^{5} \mathrm{~m}^{3}$ year ${ }^{-1}$ of sediment may be transported to the grounding line by shearing and advection of a deformable bed.
\end{abstract}

\section{INTRODUCTION}

Process monitoring in front of tidewater termini of temperate valley glaciers has been ongoing in Glacier Bay (Fig. 1), Alaska, U.S.A., since Powell (1980, 1981) began defining modern sedimentary facies and process relationships. The well-known glacial history of Glacier Bay (Field, 1947; Powell, 1984; Goldthwait, 1987; Hunter and Powell, 1995b) provides a framework for glacier behavior that, using the results of modern process studies (e.g. Mackiewicz and others, 1984; Powell, 1991; Cowan, 1992), enables us to evaluate relationships between sediment dynamics and the behavior of glacier termini (Powell, 1991; Hunter and Powell, 1995a).

The dynamics of marine-ending glaciers result from a balance among glacial, marine and sedimentary processes at the grounding line. Brown and others (1982) noted a relationship between grounding-line water depth and calving speed of Alaskan glaciers with tidewater termini. Alley (1991b) and Powell (1991) suggest that sediment dynamics may regulate grounding-line water depth. Several processes (Table 1; Fig. 2) interact to regulate the growth and collapse of sediment piles, or morainal banks, which accumulate at the grounding line. In this paper, sediment-budget data from three morainal banks in Glacier Bay are presented to provide insight into the magnitudes of processes affecting sediment dynamics in front of temperate tidewater termini in southeast Alaska.

\section{SAMPLING METHODOLOGY FOR SEDIMENT- BUDGET ANALYSES}

Our investigation focused on defining the relative importance of grounding-line processes at Grand Pacific, Margerie and Muir Glaciers (Fig. 1). A brief summary of the data collection strategy is given below.

\section{Debris distribution}

Tidewater termini are ideal for the study of debris distribution within a glacier, since the ice cliff represents a near-vertical, often transverse cross-section. Iceberg calving introduces ice from all positions of the ice cliff to the fjord. By recording the location from which each iceberg originated in the ice cliff, all representative ice facies can be sampled selectively, in accordance with an ice-facies classification scheme based on that of Lawson (1979; Fig. 3). It was possible to determine the debris distribution from debris concentrations calculated for 282 iceberg and 139 glacier ice samples (Hunter and others, 1996). 


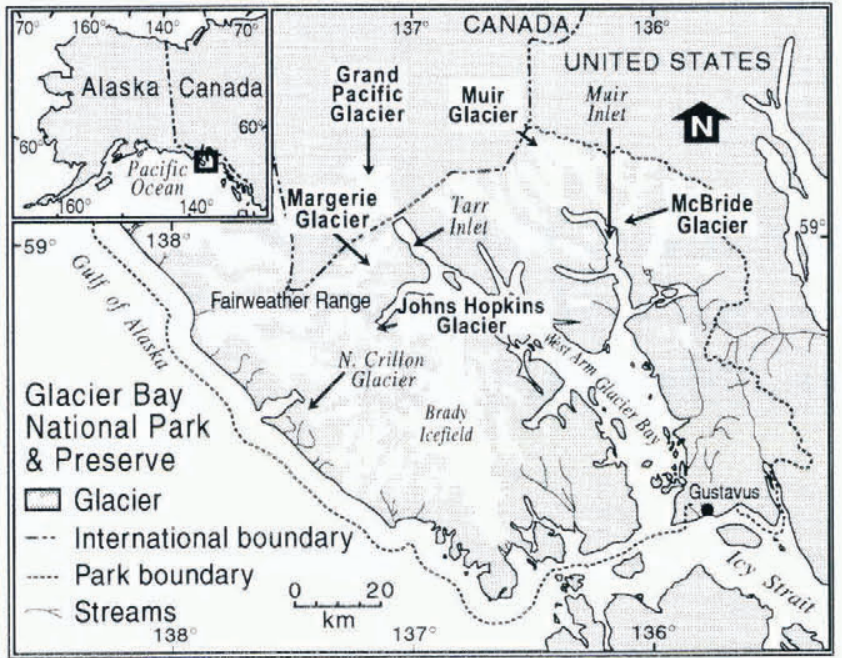

Fig. 1. Map of Glacier Bay National Park and Preserve showing the locations of (1) upper Muir Inlet and Muir Glacier, and (2) upper Tarr Inlet with Grand Pacific and Margerie Glaciers.

Basal ice layers at Grand Pacific, Margerie and Muir Glaciers are discharged into fjords below sea level, such that these layers are most often observed in icebergs. Fortunately, basally derived icebergs tend to rise vertically and their location of origin can be inferred. Sampling of these icebergs provides a valuable constraint on basal layer thickness and debris concentration.

Supraglacial debris thickness was estimated along transects near termini. Moraine thickness on Margerie and Grand Pacific Glaciers ranged from $<1 \mathrm{~mm}$ to $1.5 \mathrm{~m}$, but rarely exceeded the $0.08 \mathrm{~m}$ average estimate of Gottler (1992). Debris covers of $1 \mathrm{~mm}$ are sufficiently thick to discolor the surface, whereas a thickness of $1-2 \mathrm{~cm}$ produces a cover that appears to be nearly complete on aerial photographs. Thicker moraine covers $(0.5-1 \mathrm{~m})$ fill surface crevasses and form debris ridges and more-or-less continuous gravel surfaces.

\section{Bathymetric monitoring of glacifluvial sediment flux}

Moored lines with sediment traps were deployed in both Muir and Tarr Inlets to monitor the spatial patterns of suspension settling in these inlets Cai, 1994; Hunter, 1994). Traps suspended $1-6 \mathrm{~m}$ above the sea floor are used to represent suspended fluvial sediment flux to the sea floor. Volumes of deposited sediment were determined by plotting and contouring settling-rate data divided into plume settling (the total that accumulated on morainalbank and fluvial depocenters) and plume by-pass (sediment that became deposited downfjord from the grounding-line system; Fig. 2).

Fjord bathymetry between 1988 and 1991 was recorded nine times within $1 \mathrm{~km}$ of Muir Glacier and seven times within $2 \mathrm{~km}$ of Grand Pacific Glacier. Bathymetric monitoring enables monitoring of bedload dumping, squeeze/push and mass movements that cannot be measured directly in the ice-proximal environment. Sediment volume contributed by these processes is determined indirectly by subtracting contributions from
Table 1. Grounding-line processes

\begin{tabular}{ll}
\hline Process & Morainal- Definition \\
& bank contri- \\
& bution
\end{tabular}

Glacier debris flux:

Ice-cliff melt-out Addition Release of debris by surface melting at the terminus

Calve dumping Addition Dumping of supraglacial debris during calving events

Iceberg rafting

Transport of debris in icebergs beyond the morainal-bank toe

Glacifluvial sediment flux:

Bedload dumping Addition

Rapid deposition of coarse bedload at stream and conduit mouths

Plume settling Addition Suspension settling from overflow plumes on to the morainal bank

Plume by-pass Fine-particle transport in overflow plume distal of morainal-bank toe

Subglacial and ice marginal:

Freeze-recycling Recycling Localized subglacial freeze-on and transport to the grounding line

Squeeze/push Recycling Sediment deformation caused by groundingline fluctuations

Mass movements Removal Slides, slumps and sediment-gravity flows generated on the morainal bank

Deforming bed Addition Down-glacier advection of soft sediment below the glacier sole

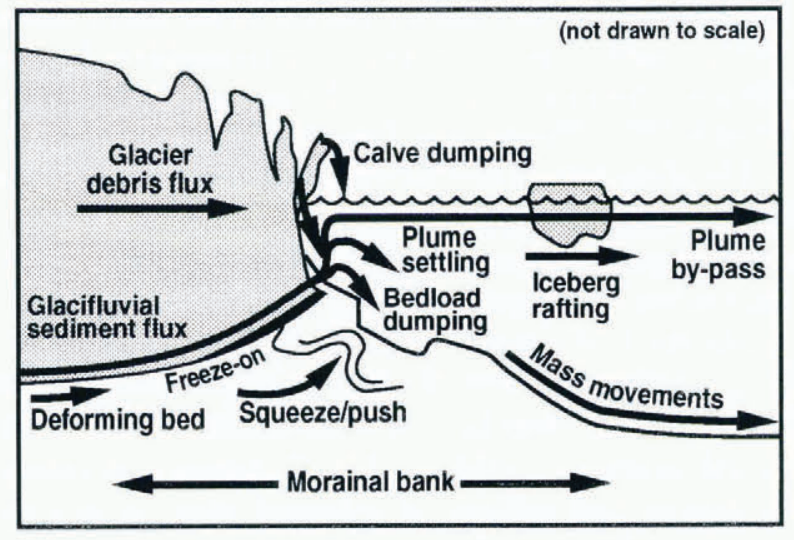

Fig. 2. Primary sedimentary processes al a tidewater terminus. 


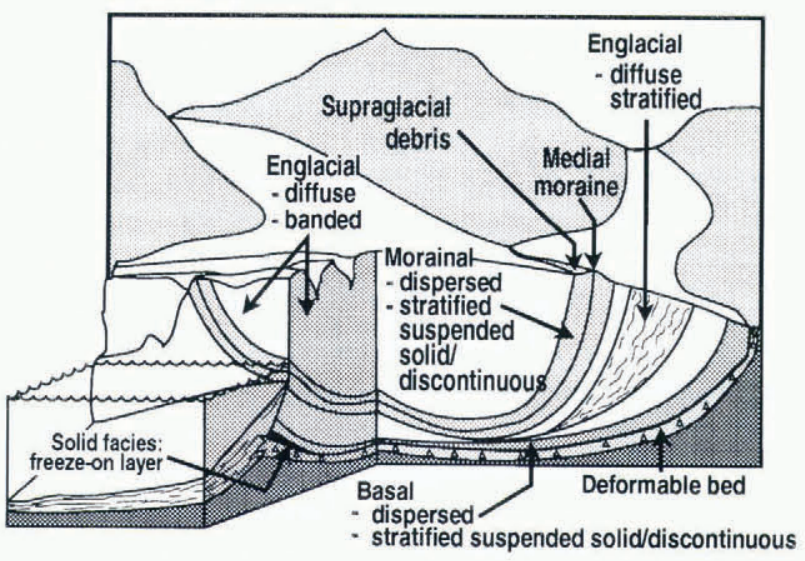

Fig. 3. General ice-facies distribution at a tidewater terminus.

plume settling, calve dumping and ice-cliff melt-out from observed spatial and temporal changes in sea-floor sediment volume. Glacifluvial dumping at point-source depocenters is illustrated on isopach maps by mounds or piles (Fig. 4; Powell, 1991), whereas morainal-bank growth away from fluvial sources is attributed to squeeze/push movements and the advection of sediment in a deforming bed. Similarly, mass-movement processes are recorded by depressions on isopach maps. Therefore, isopach maps based on repeated bathymetric surveys were used to monitor volumetric changes in the morainal bank caused by identified sedimentary processes (Figs 2 and 4 ).

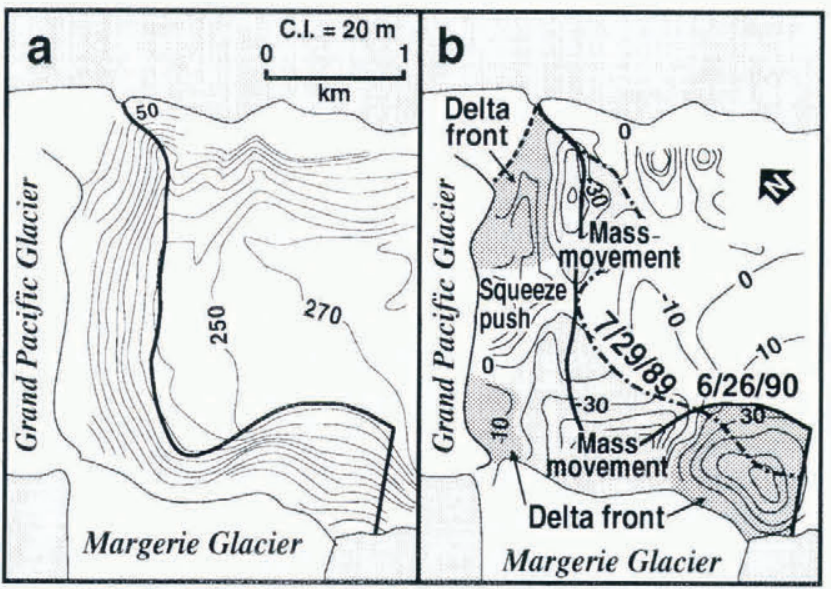

Fig. 4. Example of how sedimentary processes are monitored using bathymetric profiles and isopach maps. (a) The outer limit of the morainal bank of Margerie and Grand Pacific Glaciers in Tarr Inlel on 29 June 1990 is delineated by the extent of the active deposition slope $\left(>10^{\circ}\right)$. Submarine contours are shown with an interval of $20 \mathrm{~m}$. (b) Monitored changes in morainal-bank geometry for the period 29 July 1989 to 29 June 1990 are obtained using an isopach map. Aggradation is classified as either deltaic in origin, where located in front of glacial outwash streams, or from squeeze/push processes away from such sources. Large zones of collapse by mass-movement processes are shown in front of Margerie and Grand Pacific Glaciers. The limit of the morainal bank on 29 July 1989 is shown by a dashed line and that of 29 .June 1990 by a solid line.

\section{DATA ASSESSMENT}

Our data represent a first attempt to assess quantitatively the relative importance of various sedimentary processes in both delivering sediment to and removing it from active, dynamically changing morainal banks. The errors included in these estimates vary depending on the processes monitored, but are estimated to be within a factor of two. This is an acceptable level of accuracy since our goal was to produce an order-of-magnitude model.

Suspension-settling rates have a natural variability of less than $8 \%$ using traps with greater than $95 \%$ efficiency (Cowan, 1988), and we accordingly estimate an error of within 10\%. Measurements of debris concentrations in ice demonstrated that the debris content within an ice facies can vary by a factor of as much as 1.3 (Hunter and others, 1996), which greatly exceeds the sampling and analytical errors of $5-10 \%$. Because of natural hazards in this environment, the processes of bedload dumping, squeeze/ push and mass movements cannot be monitored directly. Individual measurements made from bathymetric profiles are estimated to be within the $90 \%$ confidence limit. However, subjective contouring and plotting of isopach maps increases the likelihood of error. We estimate that errors may be as high as $20-30 \%$, well within range for factor of two accuracy.

\section{RESULTS}

The sampling described above has produced a data set that allows us to evaluate the morainal-bank sediment budget. Powell (1991) and Hunter and Powell (1995b have reported dramatic bathymetric changes of several tens of meters and up to $100 \mathrm{~m}$ in a single field season. Such changes indicate that sediment yields in Glacier Bay are the highest documented for both glacierized and nonglacierized basins (Hallet and others, 1996).

Volumetric changes in the morainal bank $(\Delta B)$ are the sum of sediment volumes resulting from recycling $\left(R_{\mathrm{t}}\right)$, inputs $(N)$, and resedimentation processes $(M)$ active at a site for a given time period, as expressed by:

$$
\Delta B=R_{\mathrm{t}}+N-M
$$

where $R_{\mathrm{t}}$ consists of sediment volumes contributed by freeze-recycling $\left(R_{\mathrm{f}}\right)$ and squeeze/push $\left(R_{\mathrm{s}}\right)$, and $N$ is the volumetric sum of calve dumping $\left(D_{\mathrm{d}}\right)$, ice-cliff melt-out $\left(D_{\mathrm{m}}\right)$, bedload dumping $\left(F_{\mathrm{d}}\right)$, plume settling $\left(F_{\mathrm{p}}\right)$ and advection of a deforming bed $\left(B_{\mathrm{d}}\right)$ towards the grounding line (Tables 1 and 2 ).

The debris contribution from glacier ice to the morainal bank can be determined assuming plug flow near the glacier terminus, once the debris distribution is estimated and the ice flux $\left(Q_{\mathrm{i}}\right)$ has been calculated using:

$$
Q_{\mathrm{i}}=v_{\mathrm{t}} w h_{\mathrm{t}}
$$

where $v_{\mathrm{t}}$ is the average velocity near the terminus, $w$ is the glacier width, and $h_{\mathrm{t}}$ is the terminus thickness (Table 3 ). The debris flux $\left(D_{\mathrm{g}}\right)$ in basal and englacial transport is the product of the ice flux $\left(Q_{\mathrm{i}}\right)$ and the sum of the debris concentrations $\left(C_{j}\right)$ of each ice facies weighted by their 
Table 2. Sediment budgets for 1989-91 in $10^{5} \mathrm{~m}^{3}$ year ${ }^{-1}$

$\begin{array}{ccc}\text { Muir } & \text { Margerie } & \text { Grand } \\ \text { Glacier } & \text { Glacier } & \text { Pacific } \\ & & \text { Glacier }\end{array}$

Glacier debris flux:

Ice-cliff melt-out

Calve dumping

Iceberg rafting

Total

$\begin{array}{rrr}0.6 & 0.4 & 0.5 \\ 0.1 & 0.4 & 0.3 \\ 7.2 & 9.3 & 9.6 \\ 13.2^{*} & 10.1 & 10.4\end{array}$

Glacifluvial sediment flux:

Bedload dumping

Plume settling

Plume by-pass

Total

$\begin{array}{rrr}44.9 & 144.0 & 618.0 \\ 11.0 & 79.5 & 98.4 \\ 6.8 & 40.1 & 55.2 \\ 62.7 & 263.6 & 771.6\end{array}$

Subglacial and ice-marginal:

Freeze-recycling

Squeeze/push

Mass movements

Deforming bed
$2.3 \quad 1.3$

$\begin{array}{rr}0.1^{\dagger} & 6.2 \\ 283.7 & 91.5 \\ 500.0 & 626.0\end{array}$

* An additional $5.3 \times 10^{5} \mathrm{~m}^{3}$ year $^{-1}$ is dumped on to the ice-contact delta.

${ }^{\dagger}$ Based on single sample; treated as minimum estimate.

fractional volume $\left(V_{j}\right)$ of the ice in the ice cliff, such that:

$$
D_{\mathrm{g}}=Q_{\mathrm{i}} \sum_{j=1}^{n} C_{j} V_{j} .
$$

Debris fluxes calculated using Equation (3) range from $1.0 \times 10^{6}$ to $1.3 \times 10^{6} \mathrm{~m}^{3}$ year $^{-1}$ (Table 2).

The volume of debris released at the grounding line by melt-out is calculated by determining the melting rate $(R)$ using the Weeks and Campbell (1973) equation:

$$
R=6.74 \times 10^{-6} \nu^{0.8} \Delta T / l^{0.2}
$$

and recalculating Equations (2) and (3) after substituting

Table 3. Glacier parameters during study, 1988-91

\begin{tabular}{|c|c|c|c|c|c|}
\hline Average velocity & $v$ & $\mathrm{~m}_{\text {year }}{ }^{-1}$ & $380^{*}$ & 679 & 1700 \\
\hline Terminus velocity & $v_{\mathrm{t}}$ & m year $^{-1}$ & $525^{*}$ & 810 & 1700 \\
\hline Calving speed & $v$ & m year $^{-1}$ & $480^{*}$ & 776 & 1770 \\
\hline Glacier width & $w$ & $\mathrm{~m}$ & 1770 & 1900 & 880 \\
\hline $\begin{array}{l}\text { Average total } \\
\text { cliff height }\end{array}$ & $h_{\mathrm{t}}$ & $\mathrm{m}$ & $54 \quad 66$ & 90 & 90 \\
\hline Advance rate & & m year $^{-1}$ & $20-24$ & 10 & 0 \\
\hline
\end{tabular}

\begin{tabular}{llll}
\hline Variable Symbol Unit & Grand & Margerie Muir \\
& Pacific & Glacier Glacier \\
& Glacier
\end{tabular}

* Values represent portion of glacier fed only by the Ferris Tributary.

$R$ for $v_{\mathrm{t}}$. In Equation (4), $\nu$ is the boundary-layer water velocity, $\Delta T$ is the temperature difference between the ice and water and $l$ is the length of the ice cliff in contact with water along the predominant direction of water flow (Syvitski, 1989), either buoyant upwelling at Grand Pacific and Muir Glaciers or longitudinal currents at Margerie Glacier. Buoyant upwelling is estimated at $0.03 \mathrm{~ms}^{-1}$ (Mathews and Quinlan, 1975; Powell and Molnia, 1989), and longitudinal currents appear to be around $0.25 \mathrm{~m} \mathrm{~s}^{-1}$ based on iceberg-drifting rates (Hunter, 1994). The ice/water temperature difference was measured at $2.95^{\circ} \mathrm{C}$ with thermistors on a remotely controlled submersible (R.D. Powell, unpublished data). Based on these constraints, calculated ice-cliff melting rates are 21 m year $^{-1}$ (Grand Pacific Glacier), 31 m year $^{-1}$ (Margerie Glacier) and $20 \mathrm{~m}$ year $^{-1}$ (Muir Glacier). Estimates of debris released by melting range from $3.0 \times 10^{4}$ to $5.8 \times 10^{4} \mathrm{~m}^{3}$ year $^{-1}$ (Table 2).

The flux of ice discharged by calving is determined using a continuity equation:

$$
v_{\mathrm{c}}=v_{\mathrm{t}}-R-X
$$

where $v_{\mathrm{c}}$ is the calving speed (Brown and others, 1982) and $X$ is the change in glacier length (positive for advance: Meier and others, 1980). By repeating the calculations in Equations (2) and (3), this time substituting $v_{\mathrm{c}}$ for $v_{\mathrm{t}}$ (Table 3 ), estimates of iceberg rafting are $7.2 \times 10^{5}$ to $9.6 \times 10^{5} \mathrm{~m}^{3}$ year $^{1}$ (Table 2 ).

The supraglacial debris flux is the product of glacier surface velocity $\left(v_{\mathrm{t}}\right)$, moraine widths $\left(w_{\mathrm{m}}\right)$ and surficial debris thickness $(t)$. Despite the conspicuous appearance of supraglacial moraines, the supraglacial fluxes of each glacier were relatively low: $1.4 \times 10^{4}$ to $4.1 \times 10^{4} \mathrm{~m}^{3}$ year ${ }^{-1}$ (Table 2). It is assumed that all of this debris is released by gravitational processes at tidewater ice cliffs by calve dumping (Fig. 2).

Fluvial bedload dumping is calculated using isopach maps produced from short-term intervals $(10 \mathrm{~d}$ to about 1 month) that record point-source deposition (Hunter and Powell, 1995b). Use of short-term data reduces the possibility that significant amounts of sediment have been removed by mass-movement processes, so that a better understanding of the magnitude of change is achieved.

Hunter (1994) normalized these data by calculating average daily accumulation rates that were then extrapolated for the 4 month melt season (cf. Lawson, 1993). Bedload dumping was then calculated by subtracting the plume-settling component from morainal-bank depocenters indicated on isopach maps (e.g. Fig. 4). Suspensionsettling data in Table 2 indicate that plume settling onto morainal banks accounts for $1.1 \times 10^{6}$ to $9.8 \times 10^{6} \mathrm{~m}^{3}$ year ${ }^{1}$, and bedload dumping ranges from $4.9 \times 10^{6}$ to $1.4 \times 10^{7} \mathrm{~m}^{3}$ year $^{-1}$. An additional $6.8 \times 10^{5}$ to $5.5 \times 10^{6}$ $\mathrm{m}^{3}$ year ${ }^{-1}$ of sediment is transported beyond the morainal bank and deposited downfjord by plume by-pass.

Mass-movement processes occur episodically and can remove as much as $0.8 \times 10^{6}$ to $5.4 \times 10^{6} \mathrm{~m}^{3}$ of sediment within a $10-21 \mathrm{~d}$ monitoring interval and $2.5 \times 10^{7} \mathrm{~m}^{3}$ in less than a month. The largest movements appear to occur in June and decrease by almost an order of magnitude by late July and August between 1989 and 1991 , indicating instability early in the melt season. It is 
likely that considerable movement of sediment occurred prior to our sampling in June and may continue beyond the end of sampling in August. Given these limitations, a conservative estimate of sediment removed by massmovement processes may be twice that monitored in the field, or about $2.5 \times 10^{6}$ to $6.3 \times 10^{7} \mathrm{~m}^{3}$ year $^{-1}$ (Table 2 ).

Sediment transported in a deformable bed has been roughly estimated assuming a $60 \mathrm{~cm}$ thick deforming layer (e.g. Humphrey and others, 1993) and a linear velocity profile (Alley, 1991a). Subglacial sediments frozen onto basally derived icebergs have been observed in front of Grand Pacific, Johns Hopkins, Margerie, McBride and Muir Glaciers in Glacier Bay, indicating that deformable sediment is present at the soles of these glaciers. In addition, interstadial trees in Muir Inlet exhibit down-valley deformation in their upper $60-80 \mathrm{~cm}$, indicative of subglacial shearing during overriding. Assuming plug-flow conditions and average velocity of the deforming layer of about half of the surface velocity (e.g. Alley, 1991a), or about 262, 405 and 850 m year $^{-1}$ for Grand Pacific, Margerie and Muir Glaciers, respectively, we estimate that $1.3 \times 10^{5}$ to $2.3 \times 10^{5} \mathrm{~m}^{3}$ year $^{-1}$ of sediment could be transported to the grounding lines by deforming layers (Table 1). However, if soft-bed deformation is more localized, the subglacial sediment flux will be considerably less.

The processes of freeze-recycling and squeeze/push are the final components of the morainal-bank system that need to be addressed. Hunter and others (1996) estimate that the total amount of sediment moved by freezerecycling in Glacier Bay ranges from $1.0 \times 10^{4}$ to $7.2 \times 10^{5} \mathrm{~m}^{3}$ year $^{-1}$ (Table 2), from measurements of frozen sediment (the lowermost solid subfacies of Lawson (1979)) carried to the fjord surface on basally derived icebergs. Squeeze/push cannot be monitored directly, and is therefore estimated by solving Equation (1), such that $R_{\mathrm{s}}$ is the only unknown. This yields estimates that range from $2.6 \times 10^{5}$ to $2.8 \times 10^{7} \mathrm{~m}^{3}$ year $^{-1}$ for squeeze/push. Monitoring of the Margerie Glacier morainal bank demonstrates that, although squeeze/push may be the most significant process contributing to morainal-bank dynamics during the winter, it is overshadowed by massmovement removal of sediment in the summer.

\section{DISGUSSION}

A process hierarchy can be established for the morainalbank environment based on these order-of-magnitude sediment-budget analyses. First-order processes are glacifluvial dumping and mass movements, which account for the movement of $10^{6}$ to $10^{7} \mathrm{~m}^{3}$ year ${ }^{-1}$ of sediment and are the primary controls on morainal-bank growth and collapse. Glacifluvial dumping accounts for $50-80 \%$ of the glacial sediment production in a single summer, while mass-movement processes may remove more than 1.5 times the total annual sediment produced in years when morainal banks collapse (Table 2).

Second-order processes include glacifluvial plume settling, plume by-pass and advection by a deforming bed, which account for $10^{5}$ to $10^{6} \mathrm{~m}^{3}$ year ${ }^{-1}, 7-29 \%$ of the total glacial sediment yields. Squeeze/push is also assigned to second-order processes based on the analyses of Grand
Pacific and Muir Glaciers. Freeze-recycling, icebergrafting by-pass, calve dumping and ice-cliff melt-out are third-order processes, which account for the local redistribution of $10^{4}$ to $10^{5} \mathrm{~m}^{3}$ year $^{-1}(<0.1 \%$ to $9 \%)$ of sediment. Dowdeswell and Dowdeswell (1989) have observed that sedimentation rates from iceberg rafting are only an order of magnitude lower than the total sedimentation rates in Spitsbergen. The two orders of magnitude difference observed in Glacier Bay indicates an increase in the importance of glacifluvial activity in the maritime climate of southeast Alaska relative to that in a sub-polar climate.

An analysis of the behavior of termini in Glacier Bay indicates that recent advance and retreat histories are closely related to sediment dynamics. Catastrophic retreat took place in both Muir Inlet and the main arm of Glacier Bay (Fig. 1) following the Neoglacial maximum (Powell, 1980; Goldthwait, 1987). The last phase of retreat of Muir Glacier began in the 1890s but accelerated following the 1899 earthquake (Tarr and Martin, 1912; Field, 1947), which may have caused a catastrophic collapse of its morainal bank and introduced its grounding line to deep water.

Quasi-stability and subsequent advance of Margerie and Grand Pacific Glaciers in the 20th century coincide with the formation of ice-contact deltas (Hunter and Powell, 1995a). Both glaciers have been advancing for nearly 50 years behind morainal banks in a way similar to the advance of Crillon Glacier (Goldthwait and others, 1963; Powell, 1991) and Hubbard Glacier (Mayo, 1988) elsewhere in Alaska. Apparent overriding on the morainal bank by Grand Pacific Glacier during the 1970s and early 1980 s resulted in ice advancing into deeper water and an acceleration in glacier flow (Hunter and Powell, 1995a). Subsequent aggradation of grounding-line sediment has coincided with slowed glacier flow (Hunter, 1994).

Sediment dynamics are clearly not the only control on the behavior of tidewater termini in Glacier Bay and other parts of the world. Reid (1892) noted that termini tended to become pinned at fjord constrictions related to a reduction in the cross-sectional area exposed to the sea, a notion that was supported by Field (1947) and Post (1975). However, Powell (1980) found no statistical relationship to support this idea. Recent quasi-stability of the terminus of Muir Glacier has coincided with retreat into a narrow stretch of Muir Inlet where ice flux can support the calving flux (Hunter and Powell, 1995b). Rapid fjord infilling in 1986 following a period of quasistability resulted in grounding-line aggradation to sea level by 1992. Currently, Muir Glacier terminates as a terrestrial glacier and is expected to advance since it is no longer calving. It is clear, however, that the stability of tidewater termini in Glacier Bay can be influenced by sediment dynamics at the grounding line. Termini can therefore fluctuate independently of any climatic forcing.

\section{GONCLUSIONS}

Data presented in this paper should be useful in evaluating models of glacier sensitivity to sediment dynamics (e.g. Alley, 1991b) and evaluating process variations under different climatic regimes. In Glacier 
Bay, glacifluvial sediment production is as much as two orders of magnitude greater than the debris flux and constitutes $8498 \%$ of the total sediment yields. Fluvial bedload dumping accounts for $54-80 \%$ of the glacifluvial sediment production and is the single most important process adding sediment to morainal banks. Interactions between the first-order processes of glacifluvial dumping and mass movement primarily determine morainal-bank growth and collapse, and moderate grounding-line water depth. Through achieving a clearer understanding of how sediment dynamics influence the stability of glaciers with tidewater termini, we can better assess the asynchronous behavior of such glaciers in Alaska (e.g. Mann, 1986; Mayo, 1988; Powell, 1991) and other regions. Glacial systems in southeast Alaska are ideal for monitoring sediment dynamics and evaluating process relationships since their glacifluvial sediment yields are the highest known on Earth, being linked to denudation rates on the order of 10-60 $\mathrm{mm}^{-1}$ year ${ }^{-1}$ (Hallet and others, 1996).

\section{ACKNOWLEDGEMENTS}

Funding was provided by DPP 88-22098 to R.D.P.; the Geological Society of America, Sigma $\mathrm{Xi}$ and the Department of Geology at Northern Illinois University to L.E.H.; and USACRREL for D.E.L. under the Work Unit "Predicting Runoff and Sediment Yield from Partly Glacierized Basins". Logistical support was provided by the National Park Service at Glacier Bay National Park and Preserve and J. Luthy, captain of the M/V Nunatak. The authors wish to thank J. A. Dowdeswell, J. Strasser, L. Gatto and one anonymous reviewer for comments that improved the text. Assistance on the graphics was provided by L. Paulson.

\section{REFERENCES}

Alley, R.B. 1991a. Deforming-bed origin for southern Laurentide till sheets? J. Glaciol., $37(125), 67-76$.

Alley, R.B. 1991b. Sedimentary processes may cause fluctuations of tidewater glaciers. Ann. Glaciol., 15, 119-124.

Brown, C. S., M. F. Meier and A. Post. 1982. Calving speed of Alaska tidewater glaciers, with application to Columbia Glacier. U.S. Geol. Surv. Prof. Pap. 1258-C.

Cai, J. 1994. Sediment yields, lithofacies architecture and mudrock characteristics in glacimarine environments. Ph.D. thesis, Northern Illinois University.)

Cowan, E. A. 1988. Sediment transport and deposition in a temperate glacial fjord, Glacier Bay, Alaska. (Ph.D. thesis, Northern Illinois University.

Cowan, E. A. 1992. Meltwater and tidal currents: controls on circulation in a small glacial fjord. Estuarine Coastal Shelf Sci., 34 4), 381-392.

Dowdeswell, J. A. and E. K. Dowdeswell. 1989. Debris in icebergs and rates of glaci-marine sedimentation: observations from Spitsbergen and a simple model. J. Geol., 97 2), $221-231$.

Field, W. O., Jr. 1947. Glacier recession in Muir Inlet, Glacier Bay, Alaska. Geogr. Rev., 37 (3), 369399.

Goldthwait, R.P. 1987. Glacial history of Glacier Bay Park area. In Anderson, P.J., R. P. Goldthwait and G. D. McKenzie, eds. Observed processes of glacial deposition in Glacier Bay, Alaska. Columbus, $\mathrm{OH}, \mathrm{Ohio}$
State University. Byrd Polar Research Center, 5-16. (Miscellaneous Publication 236.

Goldthwait, R. P.. I. C. McKellar and C. Cronk. 1963. Fluctuations of Crillon Glacier system, southeast Alaska. LAHS Bull., 8 1), 6274.

Gottler, P. 1992. Ice-rafting at a temperate tidewater glacier, McBride Inlet, Glacier Bay, Alaska. (M.Sc. thesis, Northern Illinois University.)

Hallet, B., L. E. Hunter and J. Bogen. 1996. Rates of erosion and sediment evacuation by glaciers: a review of the evidence. Global and Planetary Change. 12, $213-235$.

Humphrey, N., B. Kamb, M. Fahnestock and H. Engelhardt. 1993. Characteristics of the bed of the lower Columbia Glacier, Alaska. J. Geophys. Res., 98 B1), 837846.

Hunter, L. E. 1994. Grounding-line systems and glacier mass balance of modern temperate glaciers and their effect on glacier stability. (Ph.D. thesis, Northern Illinois University.)

Hunter, L. E. and R. D. Powell. 1995a. Climatic controls on glacier mass balance in Glacier Bay National Park and Preserve, Alaska. In Engstrom, D., ed. Proceedings of the Third Glacier Bay Science Symposium. Anchorage, AK, U.S. Department of the Interior. National Park Service, 46-54.

Hunter, L. E. and R. D. Powell. 1995b. Effects of ice-proximal sediment dynamics on the stability of Muir Glacier, Glacier Bay, Alaska. In Engstrom, D., ed. Proceedings of the Third Glacier Bay Science Symposium. Anchorage, AK, U.S. Department of the Interior. National Park Scrvice, 29-37.

Hunter, L. E., R. D. Powell and D. E. Lawson. 1996. Flux of debris transported by ice at three Alaskan tidewater glaciers. J. Glaciol., $42(140), 110-122$.

Lawson, D. E. 1979. A sedimentological analysis of the western terminus region of the Matanuska Glacier, Alaska. CRREL Rep. 79-9.

Lawson, D.E. 1993. Glaciohydrologic and glaciohydraulic effects on runoff and sediment yield in glacierized basins. CRREL Monogr. 93-02.

Mackiewicz, N. E., R. D. Powell, P. R. Carlson and B. F. Molnia. 1984. Interlaminated ice-proximal glacimarine sediments in Muir Inlet, Alaska. Mar. Geol., 57 (1-4), $113-147$.

Mann, D. H. 1986. Reliability of a fjord glacier's fluctuations for paleoclimatic reconstructions. Qual. Res., 25 (1), 10-24.

Mathews, J.B. and A. V. Quinlan. 1975. Seasonal characteristics of water masses in Muir Inlet, a fjord with tidewater glaciers. 7. Fish. Res. Board Can., 32 10), $1693-1703$.

Mayo, L. R. 1988. Advance of Hubbard Glacier and closure of Russell Fiord, Alaska - environmental effects and hazards in the Yakutat area. U.S. Geol. Surv. Girc. 1016, 4-16.

Meier, M. F. and 7 others. 1980. Predicted timing of the disintegration of the lower reach of Columbia Glacier, Alaska. U.S. Geol. Surv. Open File Rep. 80-582.

Post, A. 1975. Preliminary hydrography and historic terminal changes of Columbia Glacier, Alaska. U.S. Geol. Surv. Hydrol. Invest. Atlas HA559

Powell, R. D. 1980. Holocene glacimarine sediment deposition by tidewater glaciers in Glacier Bay, Alaska. Ph.D. thesis, Ohio State University.

Powell, R. D. 1981. A model for sedimentation by tidewater glaciers. Ann. Glaciol., 2, $129-134$

Powell, R. D. 1984. Guide to the glacial geology of Glacier Bay, southeastern Alaska. Anchorage, AK, Alaska Geological Society.

Powell, R. D. 1991. Grounding-line systems as second-order controls on fluctuations of tidewater termini of temperate glaciers. In Anderson, J.B. and G. M. Ashley, eds. Glacial marine sedimentation; paleoclimatic significance. Boulder, CO, Geological Society of America, 75-93. GSA Special Paper 261.)

Powell, R. D. and B.F. Molnia. 1989. Glacimarine sedimentary processes, facies and morphology of the south-southeast Alaska Shelf and fjords. Mar. Geol., 85 (2-4), 359-390.

Reid, H. F. 1892. Studies of Muir Glacier. Natl. Geogr. Mag., 4, 1984.

Syvitski, J.P.M. 1989. On the deposition of sediment within glacierinfluenced fjords: oceanographic controls. Mar. Geol., 85 (2 4), $301-329$.

Tarr, R.S. and L. Martin. 1912. The earthquakes at Yakutat Bay, Alaska, in September, 1899. U.S. Geol. Surv. Prof. Pap. 69.

Weeks, W. F. and W.J. Campbell. 1973. Icebergs as a fresh-water source: an appraisal. J. Glaciol., 12 (65), 207-233. 